\title{
Üldpädevused gümnaasiumis
}

\author{
Rain Mikser ${ }^{\mathrm{ab}}$ \\ ${ }^{a}$ Tallinna Ülikooli haridusteaduste instituut \\ ${ }^{b}$ Tartu Ülikooli haridusteaduste instituut
}

\begin{abstract}
Pedaste, M. (koost ja toim). Üldpädevused gümnaasiumis. Tartu: Tartu Ülikool.
\end{abstract}

Käsiraamat „Üldpädevused gümnaasiumis“ ilmus 2020. aasta lõpus Haridusja Teadusministeeriumi ning Tartu Ülikooli haridusteaduste instituudi toel. Väljaande sisutoimetaja on Tartu Ülikooli haridustehnoloogia professor Margus Pedaste. Tema juhtis ka teose aluseks olnud projekti, mis keskendus gümnaasiumiõpilaste üldpädevuste arendamisele. Raamat sisaldab kuut peatükki, mille teemadeks on gümnaasiumi riikliku õppekava üldosas loetletud üldpädevused - läbivalt viidatakse õppekava 2014. aasta redaktsioonile. Nagu sissejuhatuses mainitud, keskendutakse kehtiva õppekava kaheksast üldpädevustest kuuele, raamat ei hõlma ettevõtlikkuspädevust ega digipädevust. Peatükkide autorite ring on võrdlemisi lai, sisaldub nii üksikautorite kui ka mitme autori ühiskirjutatud peatükke. Valdavalt Tartu Ülikooli taustaga autorite hulgas on nii kogenud haridusteadlasi kui ka neid, kelle akadeemiline tee alles üsna algusjärgus.

Kogumik on määratletud kui käsiraamat õpetajatele üldpädevuste mõistmiseks ja arendamiseks gümnaasiumiastmes. Sellise juhendmaterjalina ei ole kogumik Eestis esmakordne. Ka raamatus endas viidatakse pidevalt 2015. aasta väljaandele „Õppimine ja õpetamine kolmandas kooliastmes. Üldpädevused ja nende arendamine“, toimetajateks Eve Kikas ja Aaro Toomela. Eesti üldhariduskoolide õppekavade arenduse seisukohalt on aga nii toonasel kui siin tutvustataval raamatul laiem tähendus nii teema enda kui ka selle käsitlemise järjepidevuse mõttes.

2015. aasta väljaande toimetaja Eve Kikase väljendatud mure, et valdavalt ülikoolitöö taustaga autorite kirjutatud materjal võib tegevõpetajale jääda keeruliseks ja elukaugeks, on ajakohane praegugi. Ka viimase kümnendi uuringud Eesti õpetajatega õppekava üldküsimuste teemadel näitavad, et õppekavast mõeldes keskendub õpetaja eelkõige oma ainega seonduvale, seda suuresti riigieksamite ja tasemetööde nõudmiste tõttu. Üldpädevused, mille arendamisel puudub üks konkreetne vastutaja ning mille saavutamise hindamiseks pole seni olnud selget alust, jäävad õpetajate õppekavaarutlustes tagaplaanile. Lisaks peetakse üldpädevusi sageli enesestmõistetavaks, ainealaste pädevustega kaasnevaks, nii et kogenud õpetaja nende arendamiseks eraldi juhiseid ei vaja. 
Olekski ju kergemeelne arvata, et näiteks aastaid gümnaasiumiastmes töötanud keelte, kirjanduse, ajaloo või filosoofia õpetaja - kogenud, haritud ja laia silmaringiga - ootaks puhta lehena väliseid juhtnööre kultuuri, väärtuste, enesemääratluse või sotsiaalse pädevuse mõtestamiseks. Selles tähenduses on raamatu teema autorite jaoks kindlasti proovikivi. Samas on püüd proovikivi ületada igati tänuväärne ja vajalik: kui riik määratleb õppekava kaudu õpilaste oodatavad üldpädevused, peab keegi nende arendamise ja saavutamise küsimustega ka püsivalt ja teaduslikult tegelema. Arvestades, kui keeruline ja vaidlusterohke on kohati olnud riikliku õppekava enese arendusprotsess, on ootuspärane, et sama kehtib ka õpilaste üldpädevuste kui õppekava üldosa ühe keskse komponendi arendamise ja hindamise kohta. Seega on raamatu üks väärtusi kahtlemata autorite julgus ja ettevõtlikkus ajakohaste teemade käsitlemisel. Teine selge õnnestumine - mis otseselt seostub eelkirjeldatud 2015. aasta väljaandega - on Eesti õpilaste üldpädevuste teema käsitlemise juures teatava järjepidevuse loomine. Eelneva omamaise valdkondliku teadmise arvestamine ning sellele tuginemine on väärtus, mille puudumise all meie rahvuslik haridusteadus muidu nii sageli kannatab.

Kuigi toimetaja raamatu sissejuhatuses tagasihoidlikult mainib, et igal peatükil on erinevad autorid ja seetõttu ka mõnevõrra erinev vaade, järgitakse peatükis väheste eranditega siiski üsna läbivalt sarnast ülesehitust. Iga peatükk algab käsiteldava pädevuse defineerimisega riiklikus õppekavas, siis avatakse selle pädevuse mõiste rahvusvaheliselt tunnustatud teaduskirjanduse alusel. Järgneb kirjeldus uuringutest, mis on selle pädevuse arendamise ja hindamise kohta seni Eestis tehtud. Iga peatüki lõpuosa sisaldab näiteid ja soovitusi õpetajatele, kuidas pädevust õpilastes arendada ning hinnata. Kirjeldatakse ka tüüpilisi ohte, mis seostuvad pädevuse arendamise ja hindamise püüdlustega. Eelnimetatud järjepidevuse taotlusele lisaks võib õnnestumiseks lugeda ka seni Eestis tehtud uuringute tutvustust ning selle alusel toodud näiteid õpilaste üldpädevuste saavutatuse hindamiseks. Väljaandele lisavad usaldusväärsust sissejuhatuses lisatud tänusõnad õpetajatele, kes on panustanud üldpädevuste arendamise viiside väljatöötamisse ja testimisse. Muuhulgas on õpetajate panus oluline nimelt seetõttu, et raamatu autorite endi hulgas on ülekaalus ülikoolitöötajad ja doktorandid, märkimisväärne üldhariduskooli õpetaja kogemus avaldub vähemalt Eesti Teadusinfosüsteemis avaldatud eluloos üsna vähestel. On vajalik ja väärtuslik, et tegevõpetajad sisuliselt osaleksid üldpädevuste arendamisel, sealhulgas sellega seotud uurimistöös.

Sissejuhatuses märgib toimetaja, et kogumikus tehtud järeldused tuginevad vaid esmastele uuringutele üldpädevuste hindamisel ning süsteemselt tuleb jätkata üldpädevuste arendustegevuste, arendusmeetodite tõhususe hindamise ning muude teemakohaste uuringutega. Lugedes sellest välja vähemalt esialgset 
lubadust teemaga tulevikus jätkata, võib koos toimetaja ja autoritega siin pisut edasi arutleda raamatu kasutusvõimaluste ning järgnevate uurimissuundade ja vajalike täienduste üle. Ilmselt võtab ka gümnaasiumiõpetaja kogumiku soojalt vastu nimelt sel juhul, kui ta tajub seda mitte range juhise, vaid pigem loomingulise ajendina, millega võib vaielda ning mida kohandades ja muutes õpilaste üldpädevused enda jaoks mõtestada - parimal juhul ka ise edaspidi osaleda üldpädevuste uuringutes. Eelöeldu ei kehti mitte üksnes soovitatavate metoodiliste lahenduste, vaid ka teoreetiliste aluste kohta. Olgu üheks näiteks sotsiaalse pädevuse kui väga laia ja paljutahulise mõiste sisu liigendamine, milleks on kahtlemata teisigi võimalusi peale raamatus esitletud viie dimensiooni. Õpetaja on siin oodatud ise lisa lugema, kriitiliselt arutlema ja looma.

Tasub arutleda ka alusena kasutatava ja õpetajatele soovitatava kirjanduse üle üldisemalt. Just järjepidevuse huvides võiks pädevuste käsitlemisel enamgi tutvustada ja lugemiseks soovitada valdkonnas tunnustatud eesti teadlaste eestikeelseid väljaandeid. See hõlmab ka iga pädevuse sisu laiemas tähenduses, mitte üksnes selle pedagoogilist poolt. Näiteks Rein Raua mahukas ja tunnustatud raamat „Mis on kultuur? Sissejuhatus kultuuriteooriatesse“ (2013) võiks kindlasti kuuluda kultuuri- ja väärtuspädevuse valdkonna lugemissoovituste hulka, seda enam et siin tutvustatava raamatu vastavas peatükis otsesõnu soovitatakse õpetajatel suunata õpilasi selle küsimuse üle mõtlema. Samuti oleks õpipädevuse sisu mõistmisel ilmselt abi Edgar Krulli aastakümnete jooksul väljaantud eestikeelsetest teemakohastest teostest. Need on vaid kaks näidet; mõlemad on oma valdkonna tunnustatud professorid, kes on pika aja jooksul ja palju panustanud eestikeelsesse teaduskirjandusse. Veel tasuks kaaluda näiteks uurimismetodoloogia käsiraamatutes levinud kommet, et peatüki autor kirjeldab omaenda praktilisi kogemusi käsitletava teema õpetamisel - nii kordaminekuid kui ka ebaõnnestumisi. Selliseid kogemusi lugedes tekkib tegevõpetajal raamatu soovitustega vahetum side ning ta saab kinnitust, et soovitatu on autoril läbi proovitud ja tunnetatud.

Selgel uurimuslikul alusel, olgugi vaid esialgsel, põhinev raamat on nii õpetajale kui ka laiemale haridusavalikkusele tänuväärt lugemine ja innustav algatus. See annab lootust, et järgnevad järjepidevad uuringud ning nende põhjal valmiv kirjandus ei toeta üksnes olemasoleva õppekava rakendamist, vaid selle alusel saab ka õppekava ennast ja üldpädevuste käsitust edasi arendada. 